\title{
Effect of Some Microorganisms on Controlling Fusarium Wilt of Roselle (Hibiscus sabdariffa L.)
}

\author{
Gaafar, D.E.M. ${ }^{1}$ (D); Baka, Z.A.M. ${ }^{2}$ (D); Abou-Dobara, M.I. ${ }^{2}$; ; Shehata, H.S. ${ }^{\text {; }}$ El-Tapey, \\ H.M.A. 1 (i)
}

Received: 03 February 2021 / Accepted: 29 April 2021 / Published online: 12 May 2021.

CEgyptian Phytopathological Society 2021

\begin{abstract}
Roselle (Hibiscus sabdariffa L.) is one of the most crucial medicinal plants all over the world. The present study was carried out with the intention of solving some problems related to soil-borne diseases. Fusarium oxysporum is associated with wilt disease of roselle plant. The application of some microbiota i.e., a mixture of Pseudomonas fluorescens (PSR-11), Bacillus subtilis (BSR-8), Pleurotus ostreatus and mycorrhizeen ${ }^{\circledR}$ individually or in combination were investigated for controlling wilt disease, growth, and yield of roselle plant. The study was conducted in sandy textured soil under sprinkler irrigation of Ismailia Agricultural Research Station, Ismailia, Egypt. Under greenhouse conditions, all the tested bioagents reduced wilt incidence and increased the percentage of survived plants. The conglomeration of the bacterial mixture of Pseudomonas fluorescens and Bacillus subtilis, Pleurotus ostreatus and mycorrhizeen ${ }^{\circledR}$ was more effective in controlling wilt disease than using any of them individually. The application of the investigated bioagents showed a significant increase in phenol, photosynthetic pigments, and dehydrogenase contents, as well as root colonization percent. The obtained results showed the ability of $B$. subtilis and $P$. fluorescens to produce lytic enzymes such as $\beta-1-3$ glucanase, $\beta-1-4$ glucanase, chitinase and protease, in addition to their production of siderophore and HCN. The consortium of all microbiota gave the best results for growth and yield parameters of roselle plant.
\end{abstract}

Keywords: Roselle, Hibiscus sabdariffa, wilt, Fusarium oxysporum, biological control, Pseudomonas, Bacillus, Pleurotus, mycorrhizeen, defense-related enzymes.

*Correspondence: Gaafar, D.E.M

E-mail: doaagaafar2@gmail.com

Doaa E.M. Gaafar

(iD https://orcid.org/0000-0002-6928-6399

\section{Heba S. Shehata}

\section{Hany M.A. El-Tapey}

(iD https://orcid.org/0000-0003-2507-4754

1- Soils, Water and Environment Research Institute, Agricultural Research Center, 12619, Giza, Egypt.

\section{Zakaria A.M. Baka}

(D) https://orcid.org/0000-0001-7102-4454

\section{Mohamed I. Abou-Dobara}

(iD) https://orcid.org/0000-0001-7812-0764

2- Botany and Microbiology Department, Faculty of Science, Damietta University, Damietta, Egypt.

\section{INTRODUCTION}

Medicinal and aromatic plants are of great importunity for their multiple uses in medicine cure, cosmetics, nutrition and refreshing beverages. As well, they are used in natural flavoring and aroma additives in food industries, besides their use as a source of insecticides. They are among the most crucial agricultural export commodities for hard currency gaining and for satisfying the demands of the European markets (Mohamed et al., 2015, Al-Sayed et al., 2020).
The value of roselle exports is about $6.6 \%$ of the total Egyptian agricultural exports (FAO 2018)

Roselle (Hibiscus sabdariffa L.) belongs to the family Malvaceae, also called "karkade", is an important annual crop grown in tropical and sub-tropical regions. The commercially important part of the plant is the fleshy calyx (sepals) surrounding the fruit (capsules). The whole plant can be used as a beverage, or the dried calyces can be soaked in water to prepare a colorful cold drink or may be boiled in water and taken as a hot drink. It also has some medicinal properties. The two botanical types of roselle are Hibiscus sabdariffa var. sabdariffa, grown for its fleshy, shiny-red calyx, and Hibiscus sabdariffa var. altissima grown for its phloem fiber (Purseglove, 1974 and Mohamed et al., 2012).

One of the most urgent obstacles that limits roselle production is wilt disease. The most frequent pathogenic soilborne fungi consorted with root rot and wilt diseases are Fusarium oxysporum, Fusarium solani and Macrophomina phaseolina (Ooi and Saleh, 1999; Sie et al., 2011; Hassan et al., 2014 and Hashem et al., 2017).

Chemical treatments are still a major practice in agriculture and are widely used to control fungal soil-borne diseases. However, fungicides have two major consequences, (1) fungicide overuse threatens human health and causes 
ecological concerns; and (2) this practice leads to the emergence of fungicide-resistant microorganisms in the environment (Lamichhane et al. 2017).

Biological control is a non-chemical potential method for plant disease configuration by reducing the injurious effects of a parasite or pathogen via the use of other living entities. The rhizosphere is a nutrient-rich habitat that harbors a vast variety of bacteria and fungi that each can have neutral, beneficial or deleterious effects on the plant. Some of these organisms can improve plant growth by various mechanisms (Sahu et al., 2018).

Microbial community constitutes most extraordinary and ubiquity life on the earth, but the commonness of microorganisms is higher in nutrient-rich niches as the rhizosphere. Thus, the rhizosphere is considered the 'focal point' for microbial colonization and activity (Sindhu and Sharma, 2020).

Plant growth promoting rhizobacteria (PGPR) has a vital role in agriculture. These positive effects of PGPR have direct or indirect performance on plants, direct promotion of growth by production of metabolites that enhance plant growth, indirect growth promotion occurs via the removal of pathogens by the production of secondary metabolites. Pseudomonas spp. and Bacillus spp. are the most promising groups of rhizosphere inhabitants able to control pathogenic soilborne microorganisms (Sarhan and Shehata, 2014; Vejan et al., 2016; Tsegaye et al., 2017 and Gouda et al., 2018).

Bacillus subtilis has been widely used in agriculture attributable to its environmental safety, good biocontrol efficacy and straightforward industrial production. $B$. subtilis attains biocontrol natures, which include plant colonization, plant growth promotion, pathogen inhibition and induced systemic resistance activation (Hashem et al. 2019). In B. subtilis, biofilm formation on the root surface is critical for plant roots colonization and for biocontrol efficacy against plant pathogens (AlAli et al. 2018). Active substances production is an important aspect for assessing the biocontrol effectiveness of a beneficial strain (Gao et al. 2016). B. subtilis produces numerous substances with broad-spectrum antibacterial activity, which includes bacteriocins, lipopeptide antibiotics and antibacterial proteins ( $\mathrm{Gu}$ et al., 2021). It has been suggested that various antibacterial substances act synergistically to hinder phytopathogen growth (Alanjary and Medema 2018). The production of siderophores, phytohormones, volatile compounds, lipopeptides and phytases help B. subtilis to provoke plant growth and induce plant immune responses (Franco-Sierra et al. 2020).

Pseudomonas fluorescens was adapted to survive in soil and colonize plant roots. The microbial inoculants utilized in agriculture as biofertilizers, biocontrol agents and plant growth promoting rhizobacteria (Kiely et al., 2006). Fluorescent Pseudomonas spp. were among the most effective rhizosphere bacteria in diminishing soil-borne diseases in infected soils (Weller, 1988), where disease incidence was low, despite the presence of pathogens and environmental conditions conductive to disease popularity. Strains of Pseudomonas fluorescens enhance seed germination, shoot and root development of different crops. Some strains have the ability to devastate the fungal cell wall via secreting lytic enzymes and suppress the growth of fungal pathogens via secreting hydrogen cyanide and antibiotics. Several modes of action for antagonistic PGPR had been reported, for instance, Pseudomonas spp. production of various antimicrobial compounds and induction of plant defense mechanisms (Sindhu et al., 2016 and Zian and Aly, 2020).

Increased plant growth of arbuscular mycorrhizal fungi AM colonization is well documented. AMF can act as biological agents for alleviating the severity of disease caused by root pathogenic fungi, bacteria and nematodes (Bagyaraj, 2018).

The induction of plant defense mechanisms such as phenolic compounds production through the application of products like mushroom culture filtrate of Pleurotus ostreatus is a promising strategy to help the plant to complete its life cycle in the presence of pathogen without a marked reduction in yield and the application of such a strategy is reflected on whole plant health. (Elsakhawy et al., 2020).

The main objective of this investigation is to study the effect of some microbiota on controlling wilt disease and their effect on growth and yield of roselle plant.

\section{MATERIALS AND METHODS}

\section{1- Isolation, purification and identification of the pathogen.}

Infected roselle plants displaying typical symptoms of wilt were collected from different localities of Ismailia Governorate. Infected stem parts were cut into small pieces $(1 \mathrm{~cm})$, surface sterilized with sodium hypochlorite $(2 \%)$ for 2 minutes then immersed in distilled water 3 times 
for washing. The washed pieces were dried between sterilized filter paper till dehydration of moisture. The pieces were then transferred to sterilized potato dextrose agar medium (PDA) plates. The plates were incubated at $28^{\circ} \mathrm{C}$ for $4-5$ days until the colonies developed. Isolated fungi were purified by single conidial spores' techniques (Sinclair and Dhingra; 1995) and identified based on morphological characters as described by (Leslie and Summerell, 2006).

2- Pathogenic potential of the isolated pathogen:

The fungus recovered from the infected stems was tested for pathogenicity on roselle plants after 60 days of cultivation. Plant stems were punctured with a sterile needle, laden with a 5 $\mathrm{mm}$ disc of the isolated fungal growth (7 days old) which was confined to the stem.

\section{3- Preparation of pathogen inoculum:}

For soil infestation, $500 \mathrm{ml}$ flasks, each containing $100 \mathrm{ml}$ Potato Dextrose broth, were used for the preparation of $F$. oxysporum inoculum. Each flask was seeded with 5-mm disk of actively growing seven day's old $F$. oxysporum cultures, then incubated at $25^{\circ} \mathrm{C}$ for 7 days. The contents of the flasks were homogenized in a blender for $1 \mathrm{~min}$.

\section{4- Preparation of biocontrol agents:}

Bacillus subtilis (BSR-8), Pseudomonas fluorescens (PSR-11), Pleurotus ostreatus and mycorrhizal fungi were kindly obtained from Soil, Water and Environmental Institute, Cairo, Egypt.

\section{1- Preparation of bacterial strains:}

Pseudomonas fluorescens and Bacillus subtilis strains were cultured individually in King's broth medium in 250-ml flasks and placed on a rotary shaker at $120 \mathrm{rpm}$ for $48 \mathrm{hrs}$ at $28 \pm 1^{\circ} \mathrm{C}$. Then, the cell suspension of each strain was adjusted to provide about $10^{7} \mathrm{CFUml}^{-1}$. A mixture of the two bacterial strains was applied before planting as seed treatment in addition to their application after 30 days of planting as soil treatment at a rate of $20 \mathrm{~L} \mathrm{fed}^{-1}$.

\section{2 - Preparation of Pleurotus ostreatus:}

Glass bottles containing sterilized PD broth were inoculated with Pleurotus ostreatus. The bottles were incubated on a shaker at 1200-1500 rpm for 7 days at $25^{\circ} \mathrm{C}$. The contents of the bottles were homogenized in a blender for $1 \mathrm{~min}$ and applied before planting as seed treatment and applied after 30 days of planting as soil treatment at a rate of $20 \mathrm{~L} \mathrm{fed}^{-1}$.

\section{3- Preparation of mycorrhizal fungi:}

Mycorrhizeen ${ }^{\circledR}$ (mixture of mycorrhizal spores) was kindly obtained from Soil, Water and
Environmental Institute, Cairo, Egypt. Mycorrhizeen ${ }^{\circledR}$ was added as a recommended dose, $10 \mathrm{gm}$ mycorrhizeen $囚 /$ seed.

\section{5- Antagonistic test:}

\section{1- Antibiosis of biocontrol agents towards} the fungal pathogen:

PDA medium amended with peptone, $\mathrm{CaCO}_{3}$, and $\mathrm{MgSO}_{4}$ (3.0, 0.2 and $0.2 \mathrm{gm} / \mathrm{L}$, respectively) to examine the antagonism between the bioagents and the pathogen. The pathogenic fungi and each of the biocontrol agents were inoculated equidistantly from each other in Petri plates. Plates inoculated with the tested pathogen alone served as control. The plates were incubated at 25 $-30{ }^{\circ} \mathrm{C}$ until the control plates reached full growth and inhibition zone diameters were measured. Five replicates were used for each treatment. Mycelial growth inhibition was calculated using the formula (Fokemma, 1973):

\section{Mycelial growth inhibition $(\%)=100(C-T / C)$}

Where:

$\mathbf{C}=$ growth in control

$\mathbf{T}=$ growth in treatment.

5.2- Antibiosis of biocontrol agents towards the fungal pathogen using the biocontrol agent filtrate:

The biocontrol agent filtrates were examined against $F$. oxysporum grown on PDA medium amended with peptone, $\mathrm{CaCO}_{3}$, and $\mathrm{MgSO}_{4}$ (3.0, 0.2 and $0.2 \mathrm{gm} / \mathrm{L}$ ) to examine the antagonism between the bioagents and the pathogen. One $\mathrm{ml}$ of bioagent filtrate was transferred using sterile micropipette into the used media. The plates were centrally inoculated with the pathogenic fungi. Plates inoculated with the tested pathogen alone served as control. The plates were incubated at 25 $-30{ }^{\circ} \mathrm{C}$ until the control plates reached full growth and inhibition zone diameters were measured. Five replicates were used for each treatment. Mycelial growth inhibition was calculated by using the formula (Fokemma, 1973):

\section{Mycelial growth inhibition $(\%)=100(C-T / C)$} Where:

$\mathbf{C}=$ growth in control

$\mathbf{T}=$ growth in treatment.

\section{6- Biochemical activities of bioagents: \\ 6.1- Siderophores production:}

Trypticase soy agar (TSA) medium amended with 8-hydroxyquinoline $(50 \mathrm{mg} /$ liter) to chelate trace ferric iron $\left(\mathrm{Fe}^{3+}\right)$ in a form that is unavailable to most microorganisms and thus 8hydroxyquinoline proved to be an effective selective agent for siderophore-producing microorganisms (Alexander and Zuberer, 1991). 
Plates of TSA medium were inoculated with filter paper disc saturated with freshly grown bioagent cultures and incubated at $28^{\circ} \mathrm{C}$ for 8 days. Organisms grown on TSA medium were considered positive for siderophoric compounds production.

\section{2- Hydrogen cyanide production:}

The cultures showing biocontrol potential against pathogens were streaked on Rose Bengal Agar (RBA) medium supplemented with glycine $(4.4 \mathrm{~g} / \mathrm{L})$ for the quantitative determination of HCN from glycine by antagonistic bioagents. Inoculated plates were inverted and a strip of sterilized filter paper Whatman no. 1 saturated with $0.5 \%$ picric acid in $2 \%(\mathrm{w} / \mathrm{v})$ sodium carbonate was placed in the upper lid. The plates were then sealed with parafilm in order to contain gaseous metabolites produced by the antagonists and to allow for chemical reaction with picric acid present in the filter paper adding and incubated at $28^{\circ} \mathrm{C}$ for $24-72 \mathrm{hr}$. A change in filter paper colors from yellow to orange-brown indicate the production of $\mathrm{HCN}$. Yellow, limit cyanide production; orange, moderate cyanide production; light brown, relatively high cyanide production and brown, high cyanide production (Lorck, 2004).

\section{3- $\beta$ - 1,3 glucanase (Laminarinase):}

The enzyme-catalyzed reaction was measured with $2.5 \mathrm{mg} / \mathrm{ml}$ soluble laminarin as a substrate in a $40 \mathrm{mM}$ potassium phosphate buffer, $\mathrm{pH} 7.0$, at $30^{\circ} \mathrm{C}$, for $15 \mathrm{~min}$ to obtain the reaction-time course. The reducing power caused by the enzymatic reaction from the substrate was determined by Somogyi-Nelson a method by which absorbance at $600 \mathrm{~nm}$ was measured (Somogyi, 1945). One unit of the enzyme was defined as the "amount of enzyme", which liberates $1 \mu \mathrm{mol}$ of reducing sugar equivalent to glucose per one min under the standard assay conditions.

\section{4- $\beta$ - 1,4 glucanase (cellulase):}

Cellulase activity was determined by incubation of $900 \mu \mathrm{L}$ of $1 \%$ (CMC) carboxy methyl cellulose in $20 \mathrm{mM}$ phosphate buffer $(\mathrm{pH}$ 7.0) with $100 \mu \mathrm{L}$ of appropriate concentration of enzyme at $50^{\circ} \mathrm{C}$. After $30 \mathrm{~min}$ reaction, $1 \mathrm{~mL}$ of dinitrosalicylic acid (DNS) was added and boiled in a water bath for $15 \mathrm{~min}$ to stop the reaction. The resulted samples were then cooled to room temperature and measured the absorbance at 540 nm (Miller, 1959). One unit of cellulase activity was defined as the amount of enzyme that could hydrolyze carboxymethylcellulose and release $1 \mu \mathrm{mol}$ of glucose within 1 min reaction time at $50^{\circ} \mathrm{C}$.

\section{5- Chitinase activity:}

Colloidal chitin (1\% in $50 \mathrm{mM}$ acetate buffer) was used as the substrate for the measurement of chitinase activity. The mixture of enzyme solution $(0.5 \mathrm{ml})$ and substrate $(0.5 \mathrm{ml})$ was incubated at $40^{\circ} \mathrm{C}$ for $60 \mathrm{~min}$. After centrifugation, the amount of reducing sugar produced in the supernatant was determined by the method of Monreal and Reese (1969) with Nacetylglucosamine as a reference compound. One unit of enzyme activity was defined as the amount of enzyme that produced 1 mole of $\mathrm{N}$ acetylglucosamine per min.

\section{6- Protease:}

Protease activity (casein degradation) was determined from clearing zone in Skimmed Milk Agar (SMA) according to Nielsen et al. (1998).

\section{7- Agricultural practices:}

\section{1- Seed treatments:}

Two varieties of roselle seeds (Hibiscus sabdariffa L.) i.e., bright (c.v. Light Red Sepals) and dark (c.v. Sabahia 17) cultivars were kindly obtained from Horticultural Research Institute, Agricultural Research Center, Giza, Egypt. Seeds were surface disinfected by immersing in sodium hypochlorite $(1 \%)$ for 2 minutes, and washed several times with sterilized water, then soaked for one hour before planting in the tested treatments as following: (1)- Bacterial mixture of Bacillus subtilis + Pseudomonas fluorescens (BM), (2)- Pleurotus ostreatus (PO), (3)Mycorrhizal fungi (M), (4)- BM+ PO, (5)- BM + $\mathrm{M},(6)-\mathrm{PO}+\mathrm{M},(7)-\mathrm{BM}+(\mathrm{PO})+(\mathrm{M}),(8)-$ Infected control, (9)- healthy control.

\section{2- Greenhouse experiment}

A greenhouse experiment was carried out at Ismailia Agricultural Research Station, Agricultural Research Centre during the summer season of 2018/ 2019 to evaluate the previous treatments against roselle wilt and their effect on growth and yield of two roselle varieties. The experiment was conducted in a completely randomized design with 5 replicates. Pots $(30 \mathrm{~cm}$ in diameter) with a bottom drainage hole filled with sandy disinfested soil $(10 \mathrm{~kg})$. Soil infestation was achieved by adding $100 \mathrm{ml}$ of $F$. oxysporum (1.4 X $10^{6}$ spore/ml) pure culture grown on PD broth to each pot. The infested soil was irrigated before planting to insure its distribution in the soil. Five treated roselle seeds were sown in each pot just after irrigation. Pots were irrigated at field capacity whenever required. Before planting, all pots were received phosphorus as calcium super-phosphate $(15.5 \%$ $\mathrm{P}_{2} \mathrm{O}_{5}$ ) at a rate of $100 \mathrm{~kg} \mathrm{P}_{2} \mathrm{O}_{5}$ fed $^{\mathbf{- 1}}$. Potassium was added in the form of potassium sulphate (48 
$\% \mathrm{~K}_{2} \mathrm{SO}_{4}$ ) at a rate of $60 \mathrm{~kg} \mathrm{~K}_{2} \mathrm{SO}_{4}$ fed $^{-1}$ once before the $1^{\text {st }}$ irrigation. Nitrogen was added as ammonium sulphate $(20.5 \% \mathrm{~N})$ at the rate of 70 $\mathrm{kg} \mathrm{N}$ fed $^{-1}$ in three equal doses i.e., $1 / 3$ at cultivation time as based fertilization, $1 / 3$ at stem initiation stage and the remaining was applied at bud initiation before flowering stage.

7.3- Impact of some biocontrol agents on Fusarium wilt incidence:

The disease incidence (DI) \% was determined by recording percentages of wilted and survived plants according to the following formula:

Wilted plants $\%=$ $\frac{\text { Total No. of wilted plants }}{\text { Total No. of planted seeds }} \times 100$

Survived plants $\%=$ $\frac{\text { Total No. of survived plants }}{\text { Total No. of planted seeds }} \times 100$

8- Microbial activity after 60 days from planting:

Three replicate plants of each treatment were uprooted at 60 days after planting to determine the following parameters:

\section{1- Dehydrogenase activity:}

Dehydrogenase activity was determined according to Skujins (1976) based on the use of triphenyltetrazolium chloride (TTC) as an artificial electron acceptor. Nearly all microorganisms reduce TTC to triphenylformasan (TPF) which can be estimated after incubation at $30^{\circ} \mathrm{C}$ for $24 \mathrm{hrs}$. Because of the light sensitivity of TTC and TPF, all procedures should not be performed under diffused light; $2 \mathrm{~g}$ dry soil placed in test tubes (60 $\mathrm{ml}$ volume and $2.5 \mathrm{~cm}$ diameter) were mixed with $5 \mathrm{ml}$ of TTC solution, and the tubes were sealed with rubber stoppers and incubated for $24 \mathrm{~h}$ at $30^{\circ} \mathrm{C}$. The control contains only $5 \mathrm{ml}$ tris buffer (without TTC). After the incubation, $40 \mathrm{ml}$ acetone were added to each tube and the tubes were shaken at interval thoroughly and further incubated at room temperature for 2 hours in the dark. The soil suspension $(15 \mathrm{ml})$ was filtrated, and the optical density of the clear supernatant was measured against the blank at $545 \mathrm{~nm}$ (red colour). The enzyme activity was determined using a standard curve of TPF according to the following equation:

Dehydrogenase activity TPF $(\mu \mathrm{g} / \mathrm{D} . \mathrm{Wt} . / \mathrm{g}$ soil $)=$

$$
\frac{\text { O.D/K }}{\text { D.Wt }}
$$

Where:

O.D.= optical density

$\mathbf{K}=$ The obtained factor from the standard curve

$\mathbf{D} . \mathbf{W t}=$ dry weight of soil sample

\section{2- Microbial root colonization:}

Microbial root colonization was determined using the method described by Bilal et al. (1993). Ten centimeters of cleaned fresh root samples were chopped off and any soil particles were eliminated, then immersed with $2 \mathrm{ml}$ of 2.3 .5 chloride solution (TTC) in test tubes. Tubes were then incubated in dark at $30^{\circ} \mathrm{C}$ for 24 hours. After immersing roots in TTC, samples were left to dry in room temperature. Colonization was examined under a light microscope where plant tissues and tetrazolium reduction were visible as red color due to reduction of tetrazolium by bacterial cells. The percentage of colonization was calculated as follows:

\section{Colonization length $=$

$$
\text { Root length - Non-colonized length }
$$$$
\text { Colonization } \%=\frac{\text { Colonization length }}{\text { Root length }} \times 100
$$

\section{3- Determination of total phenol contents:}

Total phenol contents in plant leaves were estimated with the procedure given by Zieslin and Ben-Zaken (1993). One gram of tissue was homogenized in $10 \mathrm{ml}$ of the methanol $80 \%$ and agitated for $15 \mathrm{~min}$ at $70^{\circ} \mathrm{C}$. One $\mathrm{ml}$ of methanolic extract was added to $5 \mathrm{ml}$ distilled water and $250 \mu \mathrm{l}$ of Folin reagent $(1 \mathrm{~N})$, then the solution was kept at $25^{\circ} \mathrm{C}$, after $3 \mathrm{~min}, 1 \mathrm{ml}$ of a saturated solution of $\mathrm{Na}_{2} \mathrm{CO}_{3}$ and $1 \mathrm{ml}$ of distilled water were added, and the mixture was incubated at $25^{\circ} \mathrm{C}$ for $1 \mathrm{~h}$. The absorbance of the blue color developed was measured at $725 \mathrm{~nm}$. The content of total phenols was calculated according to the standard curve obtained from a Folin- reaction with a phenol solution and expected was phenol equivalent in $\mu \mathrm{g} \mathrm{g}^{-1}$ fresh tissue.

\section{4- Determination of photosynthetic pigments:}

The photosynthetic pigments (chlorophyll a, chlorophyll $\mathrm{b}$ and carotenoids) were determined quantitatively as described by Metzner et al. (1965). A known fresh weight of leaves (samples of the same fresh weight were dried at $50^{\circ} \mathrm{C}$ till constant weight to be used for final calculation), was homogenized in $85 \%$ aqueous acetone for 5 minutes (the experiment should be carried out in the dark); the homogenate was centrifuged at $4000 \mathrm{rpm}$. The supernatant was made up to known volume with $85 \%$ acetone. The absorbance was measured calorimetrically against a blank of pure acetone at wavelengths; $452.5,644$ and $663 \mathrm{~nm}$, taking into consideration the dilution made. The concentrations of pigment fractions (chlorophyll a, chlorophyll b and 
carotenoids) were calculated as $\mu \mathrm{g} / \mathrm{ml}$ by using the following equations:

$$
\begin{aligned}
& \text { Chlorophyll a }=10.3 \text { E } 663-0.918 \text { E } 644 \\
& \text { Chlorophyll b }=19.7 \text { E } 664-3.87 \text { E } 643 \\
& \text { Carotenoids }=42 . \text { E } 452.5-(0.0264 \\
& \text { chlorophyll a }+0.426 \text { chlorophyll b) }
\end{aligned}
$$

Where: $\mathrm{E}=$ absorbance

The results were expressed as $\mathrm{mg} / \mathrm{g}$ dry weight.

\section{9- Growth parameters:}

Plant samples were collected at harvest stage after 160 days. Shoot length $\left(\mathrm{cm} \mathrm{plant}^{-1}\right)$, fresh and dry shoot weight (gm plant $\left.{ }^{-1}\right)$ were determined.

\section{0- Yield parameters:}

Yield parameters expressed as fruit fresh weight $\left(\mathrm{gm} \mathrm{pot}^{-1}\right)$, fresh and dry calyx yield (gm plant $^{-1}$ ) and seed yield $\left(\mathrm{gm} \mathrm{pot}^{-1}\right)$ were calculated.

\section{1- Extraction of roselle root exudates:}

Root secretions of two roselle varieties (bright and dark) seedlings were extracted and examined for their composition and influence on the growth of different microorganisms. The procedure of Vancura and Hanzlikova (1972) was adopted. Seeds were washed several times with water and then sterilized for 2 minutes with $2 \%$ sodium hypochlorite. The sterilizing agent was removed thoroughly by washing with sterilized distilled water.

Seeds were then planted in sterilized coarse sand under greenhouse conditions. Fifteen days after planting, the above ground parts of seedlings were cut and sand with root system was repeatedly washed with sterilized distilled water to get $125 \mathrm{ml}$ of the final fluid to obtain $100 \%$ root exudates solution. The solution enriched was kept in a freezer until analysis (Shehata, 1997).

Various concentrations i.e., 10, 25, 50, 75 and $100 \%$ of roselle root exudates were prepared. Ten $\mathrm{ml}$ of each concentration were transferred respiratory using sterile micropipette into $250 \mathrm{ml}$ King's medium and PDA medium to investigate their effects on the growth of both $B$. subtilis and $P$. fluorescence and $P$. ostreatus, respectively. The appropriate media containing the previously mentioned quantities of root secretions were inoculated with $0.1 \mathrm{ml}$ of 48 hours old cultures of the tested microorganisms, then incubated at $30^{\circ}$ C. Colony counts of microbial groups were determined.

\section{2- Statistical analysis:}

Data were collected for statistical analysis according to Snedecor and Cochran (1980). Mean values were compared at a level of $\mathrm{P}<0.05$ by using Least Significance Difference (L.S.D) test. SPSS (v. 24, IBM Inc., Chicago, 1l, USA) and Costat (v. 6.400 Co Hort software., California, USA) were used for data statistical analysis.

\section{RESULTS}

\section{1- Identification of the isolated pathogen:}

The isolated fungus was identified according to its morphological characteristics and microscopic examination according to Leslie and Summerell (2006). The isolate was identified to its species by specialists in Plant Pathology. Res. Inst., Agric. Res. Center, Giza, Egypt.

\section{2- Pathogenic potential of the isolated}

pathogen:

The pathogenic potentiality of the isolated fungus was determined. Disease symptoms observed on plants grown in artificially infested soil were almost similar to those noticed under field conditions, as illustrated in Figure (1). Symptoms started with leaves yellowing then turn to brown, and the entire plant became brown with dried leaves followed by death of the entire plant.

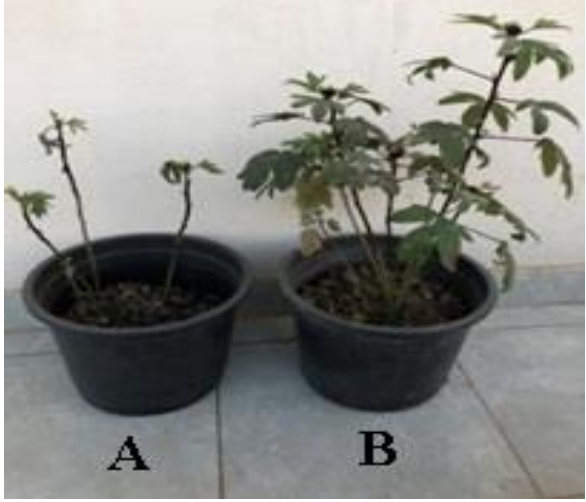

Figure (1): Wilt of roselle (Hibiscus sabdariffa L.) plants artificially infected with $F$. oxysporum (A) Infected plant (B) Control

\section{3- Antagonistic tests:}

3.1- Antibiosis of biocontrol agents towards the fungal pathogen:

Data in Table (1) reveal that P. fluorescens had significant antagonistic effect against $F$. oxysporum with a linear reduction of $79.63 \%$, followed by B. subtilis $(70.93 \%)$. While $P$. ostreatus showed the least ability to antagonize the pathogenic fungus with a reduction of 41.11 $\%$ only.

3.2- Antibiosis of biocontrol agents towards the fungal pathogen using the biocontrol agent filtrate:

The application of the microbial filtrate led to inferior effect comparing with the application of 
the agent itself. This was adverted to in Table (2), where the bacterial mixture of both B. subtilis and $P$. fluorescens showed a significant linear reduction of $75.37 \%$, however, $P$. ostreauts has no significant reduction $5.93 \%$.

Table (1): Effect of $B$. subtilis (BSR-8), P. fluorescens (PSR-11) and P. ostreauts on the linear growth in millimeter of $F$. oxysporum grown on potato dextrose agar medium:

\begin{tabular}{lcc}
\hline \multirow{2}{*}{ Treatments } & Linear growth $(\mathrm{mm})$ & Reduction $(\%)$ \\
\cline { 2 - 3 } & Mean \pm S.E.* & Mean \pm S.E** \\
\hline B. subtilis (BSR-8) & $26.2 \pm 1.856$ & $70.93 \pm 2.062$ \\
P. fluorescens (PSR-11) & $18.3 \pm 4.640$ & $79.63 \pm 5.155$ \\
Pleurotus ostreauts & $53 \pm 2.930$ & $41.11 \pm 3.255$ \\
Control & $90 \pm 0.000$ & $0 \pm 0.000$ \\
\hline L.S.D. (0.05) & 11.483 & 12.759 \\
\hline
\end{tabular}

Bacterial mixture (BM)*: Bacterial mixture of Bacillus subtilis (BSR-8) and Pseudomonas fluorescens (PSR-11). S.E**: Standard error

Table (2): Effect of bacterial mixture filtrate of both $B$. subtilis (BSR-8) and P. fluorescens (PSR11 ) and of $P$. ostreauts filtrate on the linear growth in millimeter of $F$. oxysporum grown on potato dextrose agar medium:

\begin{tabular}{lcc}
\hline \multirow{1}{*}{ Treatments } & Linear growth $(\mathrm{mm})$ & Reduction $(\%)$ \\
\cline { 2 - 3 } & Mean \pm S.E** & Mean \pm S.E** \\
\hline Bacterial mixture $(\mathrm{BM}) *$ & $22.17 \pm 22.167$ & $75.37 \pm 5.215$ \\
Pleurotus ostreauts & $84.67 \pm 0.333$ & $5.93 \pm 0.370$ \\
Control & $90 \pm 0$ & $0 \pm 0$ \\
\hline L.S.D. at 0.05 & 11.015 & 12.239 \\
\hline
\end{tabular}

Bacterial mixture (BM)*: Bacterial mixture of Bacillus subtilis (BSR-8) and Pseudomonas fluorescens (PSR-11). S.E**: Standard error

4- Biochemical activities of the bioagents:

Data presented in Table (3) point to the production of hydrogen cyanide by both strains of B. subtilis and P. fluorescens. It was also clear from the displayed data, the variation among the two strains in the siderophore production, where it was higher with $P$. fluorescens. Protease production was detected in both $B$. subtilis and $P$. fluorescens. Biocontrol agents have the ability to produce various enzymes such as $\beta-1-3$ glucanase, cellulase ( $\beta-1-4$ glucanase) and chitinase which have the capability to degrade cell wall of pathogenic fungi. Data in Table (3) show that $P$. fluorescens surpass $B$. subtilis in the production of $\beta$-1-3 glucanase, $\beta$-1-4 glucanase and chitinase $(22.2,32.2$ and $20.2 \mathrm{IU} / \mathrm{ml}$, respectively).

Table (3): Plant growth promoting (PGRP) and lytic enzymes production by Bacillus subtilis (BSR-8) and Pseudomonas fluorescens (PSR-11).

\begin{tabular}{lcccccc}
\hline \multicolumn{1}{c}{ Bioagent } & Siderophore & $\mathrm{HCN}^{*}$ & Protease & $\begin{array}{c}\beta-1,3 \\
\text { glucanase } \\
(1 \mathrm{lU} / \mathrm{ml})\end{array}$ & $\begin{array}{c}\beta-1,4 \\
\text { glucanase } \\
(1 \mathrm{lU} / \mathrm{ml})\end{array}$ & $\begin{array}{c}\text { Chitinase } \\
(\mathrm{lU} / \mathrm{ml})\end{array}$ \\
\hline B. subtilis & ++ & + & + & 17.5 & 25.5 & 15.5 \\
$P$. fluorescens & +++ & + & + & 22.2 & 32.2 & 20.2 \\
\hline
\end{tabular}

HCN*: Hydrogen cyanide

\section{5- Greenhouse experiment:}

\section{1- Impact of some biocontrol agents on}

Fusarium wilt incidence:

The efficacy of bioagents as seed treatment and soil application against disease incidence of Bright and Dark roselle varieties was assessed under greenhouse conditions. Results in Figure (2) draw attention to the lack of significant differences among varieties and among treatments in the disease incidence. It was clear that healthy control showed the highest level of plant survival in both Bright and Dark varieties, 88 and $84 \%$, respectively. Followed by the application of the mixture of $B$. subtilis, $P$. fluorescens, $P$. ostreatus and mychorrhizeen $\AA$ in both Bright and Dark varieties, 80 and $64 \%$, 
respectively. While the least plant survival percentage was recorded in the infected control, being $72 \%$ in Bright variety and $56 \%$ in the Dark variety. The highest wilted plant percentage was reported to the infected control grown in infested soil in Dark variety (44\%), and $36 \%$ to the bacterial mixture treatment in Bright variety.

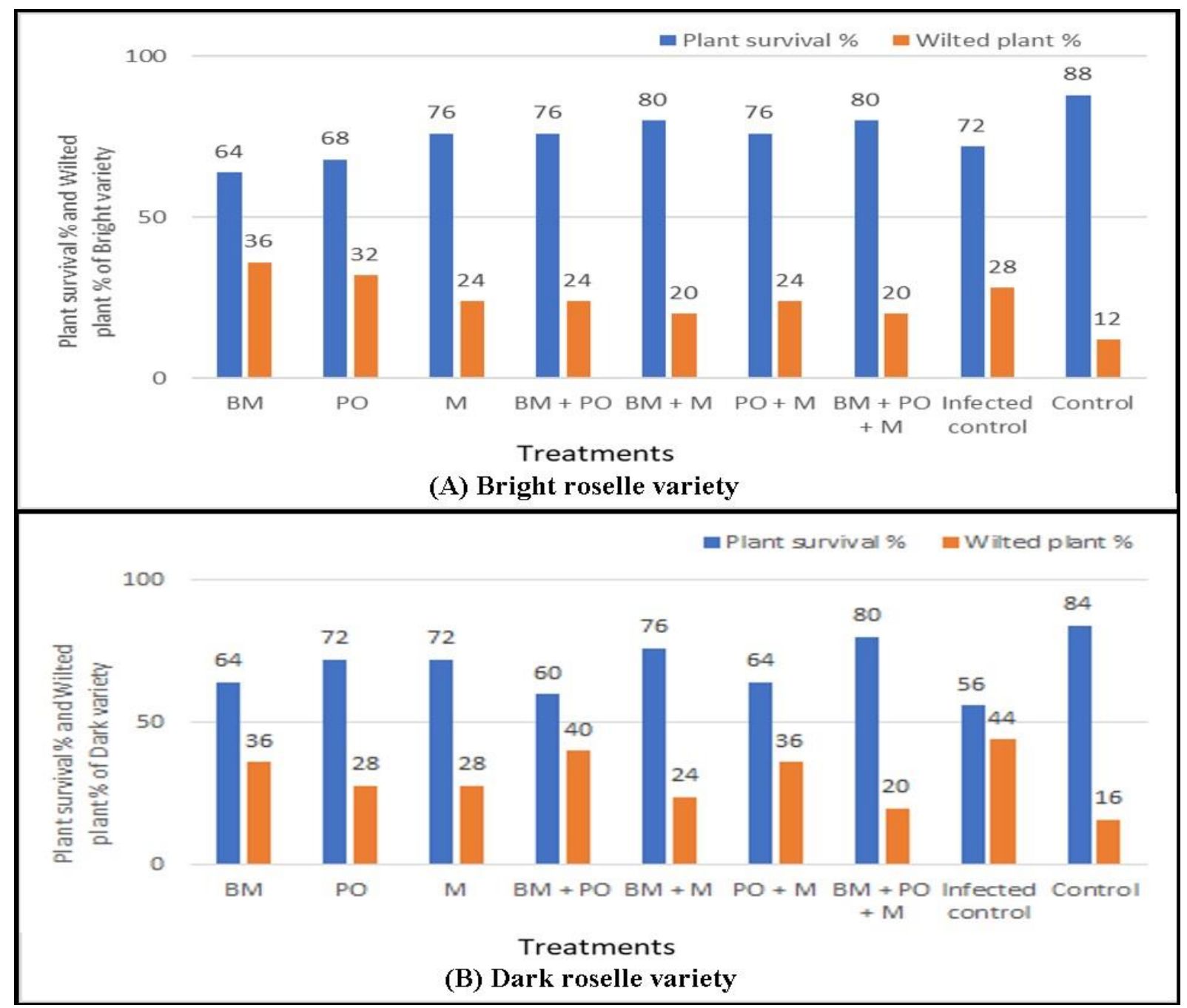

Figure (2): Percentages of wilted \% and survived plants $\%$ as influenced by some bioagents on Bright (A) and Dark (B) roselle varieties grown in artificially infested soil by $F$. oxysporum under greenhouse conditions. Data are expressed as a mean \pm standard error, L.S.D. test (ANOVA). Statistical significance was considered as $P<0.05$.

BM: Bacterial mixture, PO: P. ostreatus, M: Mycorrhiza.

\section{2 - Dehydrogenase activity:}

Data presented in Figure (3) show the ability of beneficial microorganisms to exist in a plenty population in the rhizospheric area and in soil. The existence of these microbes significantly increased the activity of dehydrogenase especially the application of the mixture of all microbes that led to the highest significant value which recorded $142 \mu \mathrm{g}$ TPF/g dry soil for the Bright variety and $134.9 \mu \mathrm{g}$ TPF/g dry soil for the Dark variety. The infected control recorded the least value of dehydrogenase, being $40.2 \mu \mathrm{g}$ $\mathrm{TPF} / \mathrm{g}$ dry soil for the Bright variety and $32.1 \mu \mathrm{g}$ $\mathrm{TPF} / \mathrm{g}$ dry soil for the Dark variety.

\section{3-Root colonization}

Referring to root colonization percent in response to inoculation with $B$. subtilis, $P$. fluorescens, $P$. ostreatus and mycorrhizeen ${ }^{\circledR}$ and their interaction with two roselle varieties, data in Figure (4) explicate the interaction effect between the varieties and the bioagents. Concerning the Bright variety, applying the bioagents mixture gave the highest colonization rate $(90 \%)$, while applying $P$. ostreatus abandoned had no effect compared with the infected control (10\%). Referring to the Dark variety, the application of $P$. ostreatus and mycorrhiza appeared to have the highest colonization rate $(90 \%)$. 


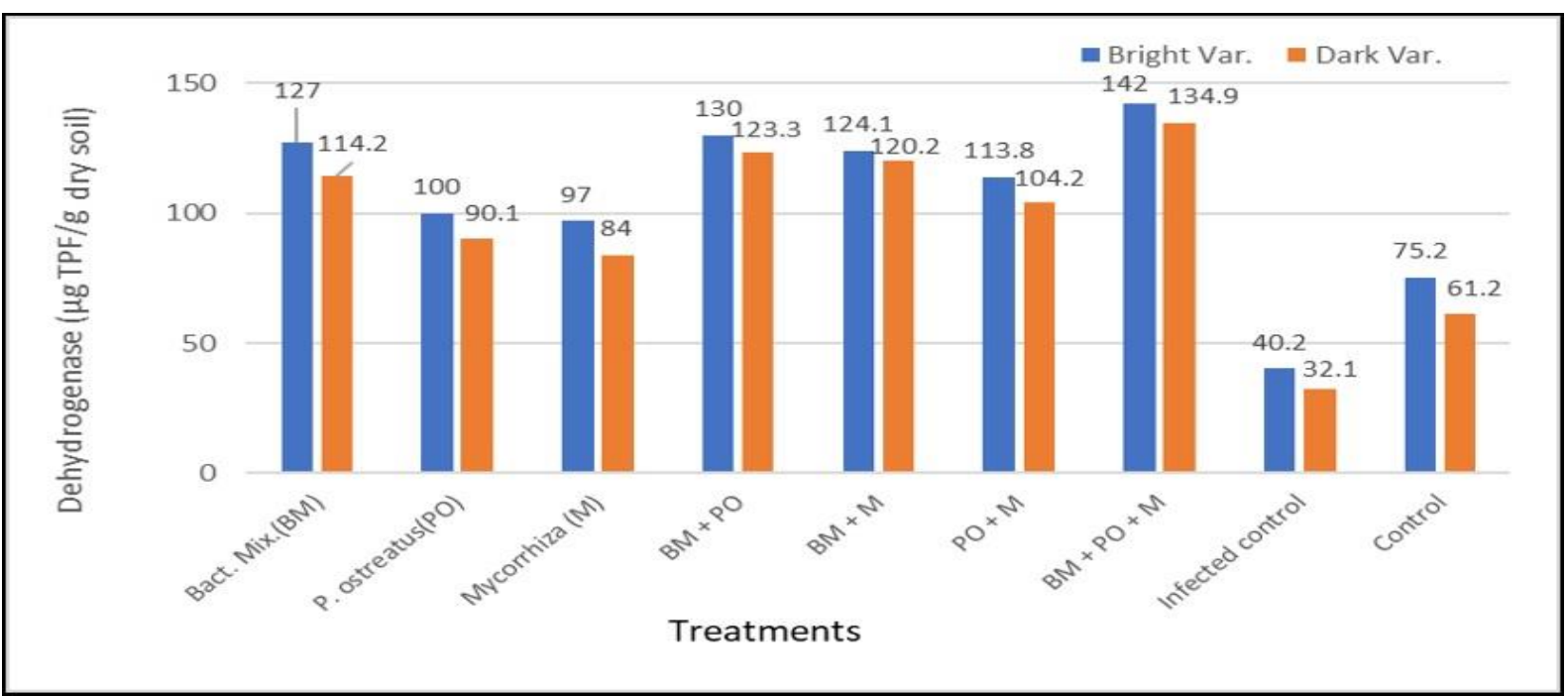

Figure (3): Biological influence on dehydrogenase content of Bright and Dark roselle varieties grown in artificially infested soil by $\boldsymbol{F}$. oxysporum under greenhouse conditions. Data are expressed as a mean \pm standard error, L.S.D. test (ANOVA). Statistical significance was considered as $\mathbf{P}<\mathbf{0 . 0 5}$.

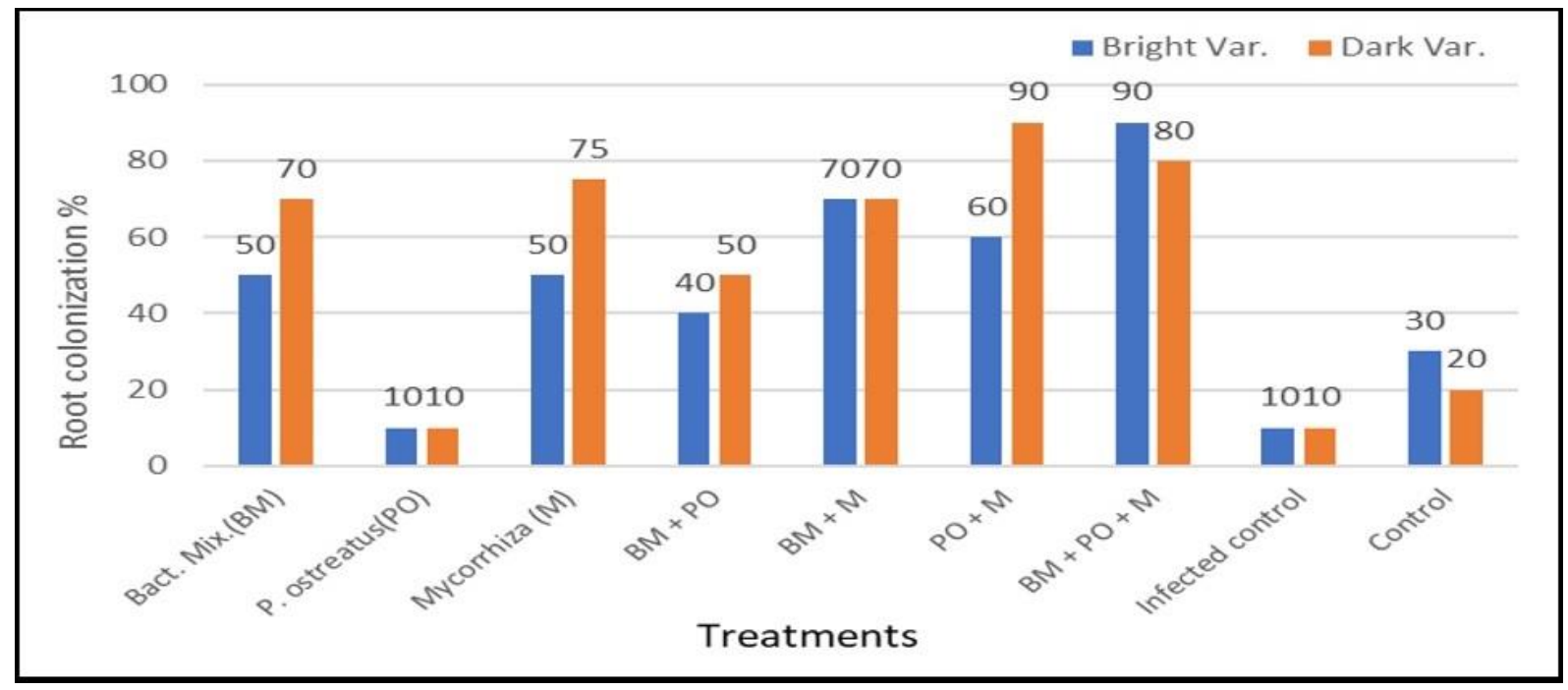

Figure (4): Root colonization \% as affected by some microbiota on Bright and Dark roselle varieties grown in artificially infested soil by $F$. oxysporum under greenhouse conditions. Data are expressed as a mean \pm standard error, L.S.D. test (ANOVA). Statistical significance was considered as $\mathrm{P}<0.05$.

\section{4- Determination of total phenols:}

Determination of total phenols content in leaves of Bright and Dark roselle varieties demonstrated the significant difference among treatments, which is apparent in Figure (5). Data detected that in the Bright variety the mixture of Bacillus subtilis, Pseudomonas fluorescens and mychorrizeen ${ }^{\circledR}$ possess the highest value among treatments $(4.98 \mathrm{mg} / \mathrm{g}$ dry wt. $)$, while the healthy control was the least value $(0.94 \mathrm{mg} / \mathrm{g}$ dry wt.). Whereas, in the Dark variety the treatment using all the tested bioagents showed the highest value ( $3.95 \mathrm{mg} / \mathrm{g}$ dry wt.) and the control was the least (0.84 mg/g dry wt.).

\section{5- Determination of photosynthetic} pigments:

Regarding the photosynthetic pigments in roselle plant, Figure (6) reveal that in both Bright and Dark varieties, the used microbiota insignificantly increased chlorophyll $\mathrm{a}$ and $\mathrm{b}$ compared with the control. It is obvious from the given results that carotenoid attained the highest significant contents in both Bright and Dark varieties when utilizing the mixture of $B$. subtilis, $P$. fluorescens, $P$. ostreatus and mychorrizeen ${ }^{\circledR}$ $(0.82$ and $0.6 \mathrm{mg} / \mathrm{g}$ dry wt., respectively) in comparable with the infected control which attained the least value $(0.33$ and $0.4 \mathrm{mg} / \mathrm{g}$ dry wt., respectively). 


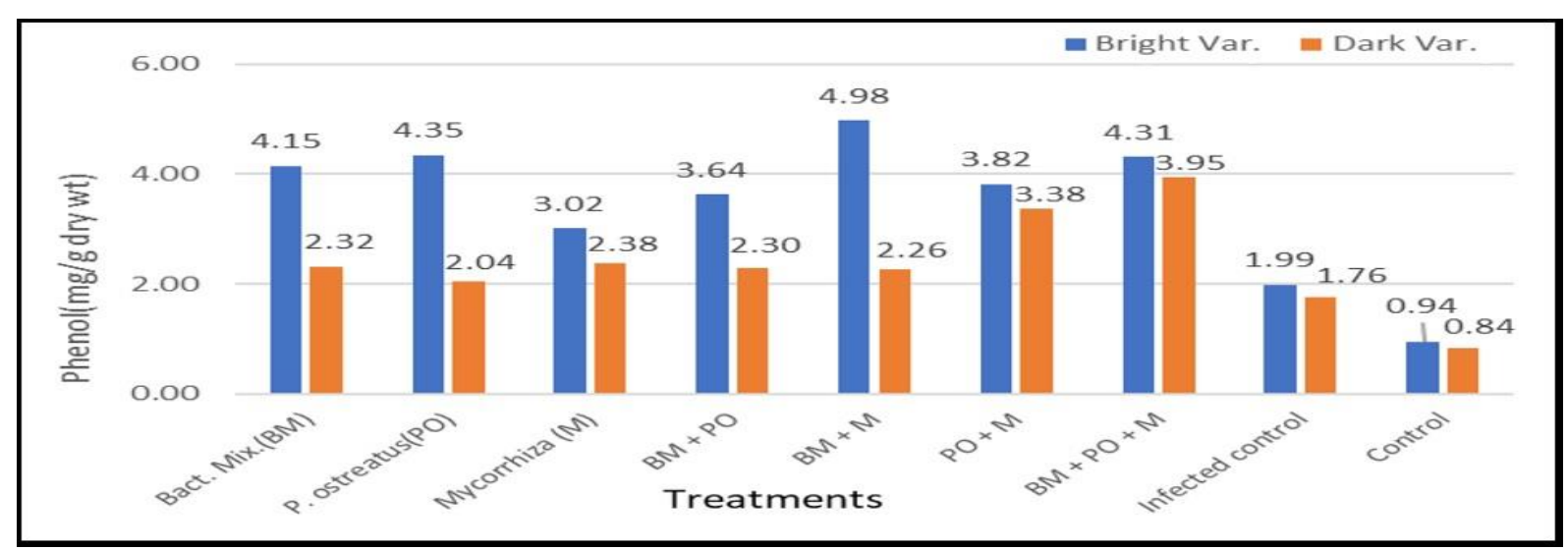

Figure (5): Biological influence on phenol content of Bright and Dark roselle varieties grown in artificially infested soil by $F$. oxysporum under greenhouse conditions. Data are expressed as a mean \pm standard error, L.S.D. test (ANOVA). Statistical significance was considered as $P<0.05$.

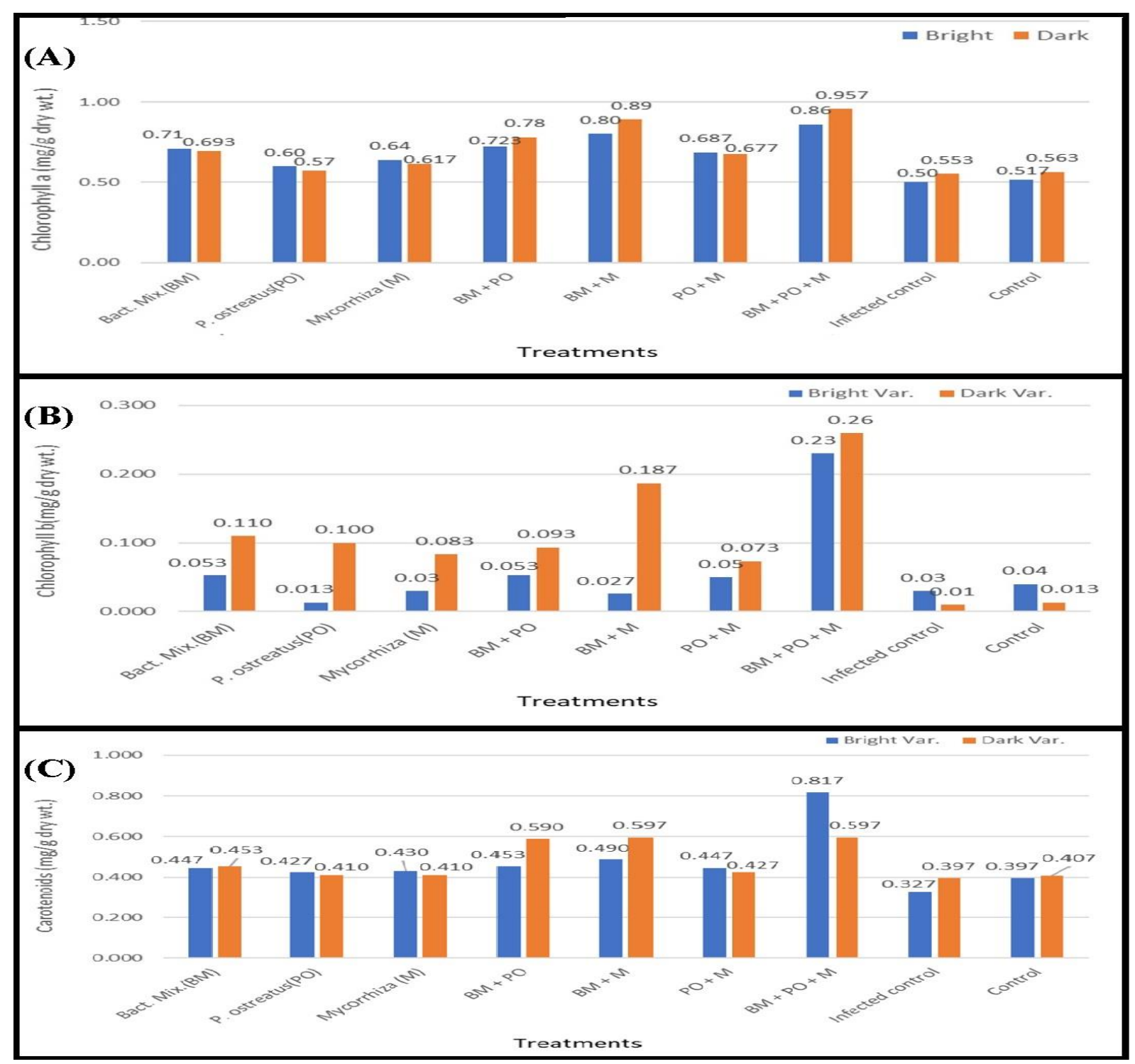

Figure (6): The impact of some microorganisms on photosynthetic pigment contents (chlorophyll a (A), chlorophyll b (B) and carotenoids (C)) of Bright and Dark roselle varieties grown in artificially infested soil by $F$. oxysporum under greenhouse conditions. Data are expressed as a mean \pm standard error, L.S.D. test (ANOVA). Statistical significance was considered as $P<0.05$. 


\section{6- Growth parameters:}

Growth parameters expressed as shoot height, fresh and dry weight were significantly affected by microbial inoculation. Data in Table (4) show that regarding the Bright variety, inoculation of the bacterial mixture together with mycorrhizeen ${ }^{\circledR}$ was superior in shoot length which recorded $88.1 \mathrm{~cm}^{-1 a n t^{-1}}$ and shoot dry weight 20.8 gm plant $^{-1}$, while inoculation of $P$. osteratus and mycorrhizeen ${ }^{\circledR}$ showed the highest shoot fresh weight with $79.5 \mathrm{gm} \mathrm{plant}^{-1}$.
Regarding the Dark variety, implementation of $P$. osteratus showed the highest shoot height value which was $85.9 \mathrm{~cm}$ plant $^{-1}$, implementation of the mixture of all microbes showed the highest shoot fresh weight with $182.46 \mathrm{gm} \mathrm{plant}^{-1}$, and implementation of the bacterial mixture in addition to $P$. osteratus showed the highest shoot dry weight with $31.2 \mathrm{gm}$ plant $^{-1}$. In general, data indicated a markedly significant difference between the two varieties in morphological characterization.

Table (4): Impact of some bioagents on some shoot parameters of Bright and Dark roselle varieties grown in artificially infested soil by $F$. oxysporum under greenhouse conditions.

\begin{tabular}{|c|c|c|c|c|c|c|}
\hline \multirow{4}{*}{ Treatments } & \multicolumn{6}{|c|}{ Shoot parameters } \\
\hline & \multicolumn{2}{|c|}{ Height (cm/plant) } & \multicolumn{2}{|c|}{ Fresh wt. (gm/plant) } & \multicolumn{2}{|c|}{ Dry wt. (gm/plant) } \\
\hline & Bright & Dark & Bright & Dark & Bright & Dark \\
\hline & $\underset{* * *}{\text { Mean } \pm \text { S.E }}$ & $\underset{* * *}{\text { Mean } \pm \text { S.E }}$ & $\underset{* * *}{\text { Mean } \pm \text { S.E }}$ & $\underset{* * *}{\text { Mean } \pm \text { S.E }}$ & $\underset{* * *}{\text { Mean } \pm \text { S.E }}$ & $\underset{* * *}{\text { Mean } \pm \text { S.E }}$ \\
\hline Bact. Mix. * (BM) & $81.0 \pm 1.46$ & $79.5 \pm 2.03$ & $60.0 \pm 2.89$ & $65.0 \pm 0.57$ & $16.2 \pm 0.50$ & $12.7 \pm 0.52$ \\
\hline P. ostreauts (PO) & $64.4 \pm 0.72$ & $85.9 \pm 1.45$ & $42.5 \pm 0.65$ & $70.0 \pm 0.63$ & $11.2 \pm 0.39$ & $14.57 \pm 0.34$ \\
\hline Mycorrhizae (M) & $73.5 \pm 0.63$ & $69.3 \pm 0.96$ & $60.0 \pm 1.36$ & $57.0 \pm 0.47$ & $11.9 \pm 0.34$ & $19.5 \pm 0.66$ \\
\hline $\mathrm{BM}+\mathrm{PO}$ & $87.5 \pm 1.18$ & $75.5 \pm 1.29$ & $50.0 \pm 2.47$ & $173.0 \pm 0.72$ & $16.5 \pm 0.53$ & $31.2 \pm 0.49$ \\
\hline $\mathrm{BM}+\mathrm{M}$ & $88.1 \pm 1.15$ & $73.3 \pm 0.44$ & $72.5 \pm 0.77$ & $57.5 \pm 0.42$ & $20.8 \pm 0.35$ & $14.01 \pm 0.40$ \\
\hline $\mathrm{PO}+\mathrm{M}$ & $71.7 \pm 1.05$ & $68.9 \pm 0.32$ & $79.5 \pm 0.61$ & $90.0 \pm 0.45$ & $17.8 \pm 0.29$ & $27.3 \pm 0.58$ \\
\hline $\mathrm{BM}+\mathrm{PO}+\mathrm{M}$ & $77.4 \pm 0.86$ & $74.5 \pm 1.62$ & $76.3 \pm 0.49$ & $182.5 \pm 1.15$ & $18.8 \pm 0.63$ & $31.1 \pm 0.72$ \\
\hline Infected control & $55.5 \pm 0.42$ & $53.3 \pm 0.46$ & $15.0 \pm 0.50$ & $15.5 \pm 0.28$ & $5.3 \pm 0.31$ & $6.5 \pm 0.25$ \\
\hline Control & $56.5 \pm 1.04$ & $54.2 \pm 1.39$ & $25.0 \pm 0.71$ & $49.4 \pm 0.56$ & $5.0 \pm 0.17$ & $9.4 \pm 0.31$ \\
\hline L.S.D (0.05) & 2.84 & 3.56 & 4.15 & 1.8 & 1.18 & 1.43 \\
\hline F. Test & \multicolumn{2}{|c|}{$* *$} & \multicolumn{2}{|c|}{$* *$} & \multicolumn{2}{|c|}{$* *$} \\
\hline LSD at $0.05 \mathrm{~V} * \mathrm{~B}$ & \multicolumn{2}{|c|}{3.194} & \multicolumn{2}{|c|}{3.151} & \multicolumn{2}{|c|}{1.269} \\
\hline
\end{tabular}

Bact. Mix. * (BM): Bacterial mixture of Bacillus subtilis (BSR-8) and Pseudomonas fluorescens (PSR-11), S.E***: Standard error, $\mathrm{V}=$ Variety, $\mathrm{B}=$ Bioagents

\section{7- Yield parameters:}

Biological influence on some yield parameters is expressed in Table (5). Data indicated that the impact of inoculation of the mixture of Bacillus subtilis, P. fluorescens, $P$. ostreatus and mychorrizeen $®$ of the two varieties was significantly reflected on the fruit fresh weight, the calyx fresh weight and calyx dry weight. The mixture of all bioagents was superior in both Bright and Dark varieties giving 178 and $146 \mathrm{gm} /$ pot fruit fresh weight, respectively; 82 and $72 \mathrm{gm} /$ pot calyx fresh weight respectively; 7.3 and $7.4 \mathrm{gm} /$ pot calyx dry weight, respectively; along with14 and 12.9 $\mathrm{gm} /$ pot air dried fresh seed weight. The infected control reported the inferior yield in both Bright and Dark varieties.

\section{6- Growth pattern of microbiota in culture media supplemented with roselle root exudes}

Microbial candidates of inocula applied in the greenhouse experiments were separately examined for their response to root excretions of Bright and Dark roselle varieties when added to the culture medium at various concentrations. Presence of root exudates in the medium significantly increased growth of both $P$. fluorescens and B. subtilis. Such effect was more pronounced with a concentration $100 \%$ in both varieties as shown in Figure (7). Higher numbers were scored with the Bright roselle variety. $P$. fluorescens multiplied better than $B$. subtilis when inoculated in a culture medium supplied with the same quantities of roselle root exudates. 
Table (5): Some yield parameters as affected by some biological agents of Bright and Dark roselle varieties grown in artificially infested soil by $F$. oxysporum under greenhouse conditions.

\begin{tabular}{|c|c|c|c|c|c|c|c|c|}
\hline \multirow{4}{*}{ Treatments } & \multirow{2}{*}{\multicolumn{2}{|c|}{$\begin{array}{l}\text { Fruit fresh wt. } \\
\qquad(\mathrm{gm} / \mathrm{pot})\end{array}$}} & \multicolumn{4}{|c|}{ Calyx } & \multirow{2}{*}{\multicolumn{2}{|c|}{$\begin{array}{l}\text { Seeds fresh wt. } \\
\text { (gm /pot) air dried }\end{array}$}} \\
\hline & & & \multicolumn{2}{|c|}{ Fresh wt. (gm /pot) } & \multicolumn{2}{|c|}{ Dry wt. (gm /pot) } & & \\
\hline & Bright & Dark & Bright & Dark & Bright & Dark & Bright & Dark \\
\hline & 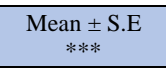 & $\underset{* * *}{\operatorname{Mean} \pm \text { S.E }}$ & $\begin{array}{c}\text { Mean } \pm \text { S.E } \\
* * *\end{array}$ & $\underset{\substack{\text { Mean } \pm \text { S.E } \\
* * *}}{ }$ & $\begin{array}{c}\text { Mean } \pm \text { S.E } \\
* * * *\end{array}$ & $\begin{array}{c}\text { Mean } \pm \text { S.E } \\
* * * * \\
\end{array}$ & $\underset{* * * *}{M_{* *} \pm \text { S.E }}$ & $\begin{array}{c}\text { Mean } \pm \text { S.E } \\
* * * * \\
\end{array}$ \\
\hline Bact. Mix. *(BM) & $140.0 \pm 3.39$ & $124.0 \pm 0.61$ & $62.0 \pm 0.36$ & $60.0 \pm 0.44$ & $5.7 \pm 0.21$ & $6.9 \pm 0.26$ & $13.0 \pm 0.51$ & $11.3 \pm 0.29$ \\
\hline P. ostreauts (PO) & $110.0 \pm 3.24$ & $86.6 \pm 0.77$ & $40.0 \pm 0.71$ & $22.8 \pm 0.77$ & $5.0 \pm 0.25$ & $4.7 \pm 0.30$ & $10.0 \pm 0.44$ & $9.6 \pm 0.4$ \\
\hline Mycorrhizae (M) & $118.0 \pm 3.31$ & $98.0 \pm 0.62$ & $41.0 \pm 0.79$ & $38.8 \pm 0.81$ & $5.1 \pm 0.24$ & $5.2 \pm 0.16$ & $11.0 \pm 0.5$ & $8.2 \pm 0.38$ \\
\hline $\mathrm{BM}+\mathrm{PO}$ & $152.6 \pm 1.68$ & $146.0 \pm 0.94$ & $64.0 \pm 0.42$ & $62.0 \pm 0.97$ & $6.3 \pm 0.22$ & $7.0 \pm 0.33$ & $13.0 \pm 0.45$ & $12.1 \pm 0.37$ \\
\hline $\mathrm{BM}+\mathrm{M}$ & $156.0 \pm 1.73$ & $127.4 \pm 0.79$ & $68.0 \pm 0.67$ & $61.0 \pm 0.96$ & $6.4 \pm 0.28$ & $6.9 \pm 0.32$ & $14.0 \pm 0.53$ & $11.7 \pm 0.41$ \\
\hline $\mathrm{PO}+\mathrm{M}$ & $128.0 \pm 1.12$ & $118.0 \pm 0.58$ & $46.0 \pm 0.67$ & $58.0 \pm 0.88$ & $5.4 \pm 0.23$ & $5.9 \pm 0.32$ & $12.0 \pm 0.53$ & $10.2 \pm$ \\
\hline $\mathrm{BM}+\mathrm{PO}+\mathrm{M}$ & $178.0 \pm 3.76$ & $146.0 \pm 0.72$ & $82.0 \pm 0.75$ & $72.0 \pm 0.75$ & $7.3 \pm 0.45$ & $7.4 \pm 0.41$ & $14.0 \pm 0.56$ & $12.9 \pm 0.3$ \\
\hline Infected control & $80.3 \pm 1.00$ & $82.6 \pm 0.77$ & $27.0 \pm 0.39$ & $20.4 \pm 0.68$ & $4.6 \pm 0.28$ & $3.2 \pm 0.27$ & $7.2 \pm 0.36$ & $6.2 \pm 0.17$ \\
\hline Control & $104.0 \pm 1.82$ & $86.2 \pm 0.68$ & $38.0 \pm 1.30$ & $21.0 \pm 0.47$ & $5.0 \pm 0.26$ & $4.1 \pm 0.33$ & $7.4 \pm 0.32$ & $7.4 \pm 0.22$ \\
\hline L.S.D (0.05) & 7.31 & 2.09 & 2.08 & 2.2 & 0.79 & 0.88 & 1.35 & 1.13 \\
\hline F. Test & \multicolumn{2}{|c|}{$* *$} & \multicolumn{2}{|c|}{$* *$} & \multicolumn{2}{|c|}{$* *$} & \multicolumn{2}{|c|}{ Ns } \\
\hline LSD at $0.05 \mathrm{~V} * \mathrm{~B}$ & \multicolumn{2}{|c|}{5.252} & \multicolumn{2}{|c|}{1.978} & \multicolumn{2}{|c|}{0.811} & \multicolumn{2}{|c|}{ - } \\
\hline
\end{tabular}

Bacterial mixture * (BM): Bacterial mixture of Bacillus subtilis (BSR-8) and Pseudomonas fluorescens (PSR-11), S.E***: Standard error, $\mathrm{V}=$ Variety, $\mathrm{B}=$ Bioagents.

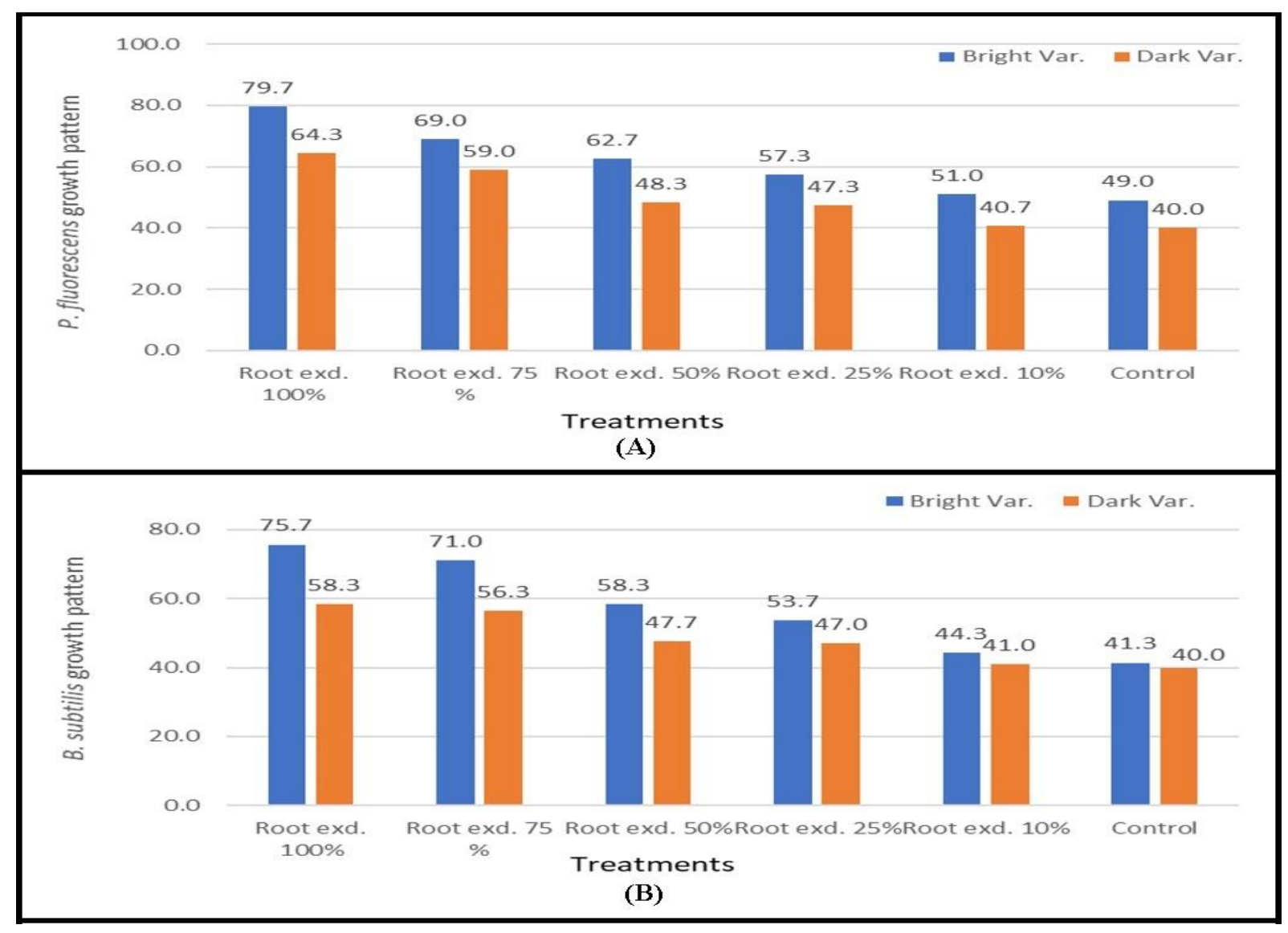

Figure (7): Effect of Bright and Dark roselle root exudates on growth pattern of (A)P. fluorescens and (B) B. subtilis. Data are expressed as a mean \pm standard error, L.S.D. test (ANOVA). Statistical significance was considered as $P<0.05$. 


\section{DISCUSSION}

Roselle plant is considered being one of the crucial medicinal plants in Egypt. Its extracts became a basic material in medicine, cosmetic and food industries. Roselle cultivations concentrate in Upper Egypt. The cultivation area is increasing progressively attributable to the importance of the roselle plant (Ottai et al., 2011).

Results of the present investigation revealed the ability of the bacterial isolates, i.e., B. subtilis and $P$. fluorescens to antagonize the pathogenic fungus $F$. oxysporum. The inhibition in the growth could be attributed to antibiosis, hyperparasitism or production of chitinase, $\beta-1,3$ glucanase and $\beta-1,4$ glucanase which degrade the cell wall leading to lyses of mycelium of the pathogen. El-Gamal et al. (2016) reported a similar inhibitory result with $B$. subtilis and $P$. fluorescens against tomato root rot, where $B$. subtilis can cause $57.8 \%$ reduction against $F$. solani while $P$. fluorescens led to $81.1 \%$ reduction.

The production of various plant growth promoting and anti-fungal substances positively affected plant growth and resistance. Siderophore production was also noticed which enhances iron uptake by the plant which in turn enhances plant growth (Sarhan and Shehata 2014 and Gouda et al., 2018). Voisard et al. (1989) found that HCN stimulated root hair formation.

In the present work, it was found that the mixture of bioagents decreased disease incidence than individual ones. Bagyaraj (2018) assumed that the protection mechanisms used by PGPR against the pathogen are: competition for space and nutrients, modification of $\mathrm{Fe}$ and $\mathrm{Mn}$ availability, liberation of antibiotics and $\mathrm{HCN}$, plant growth promotion by modification of plant hormone balance, and stimulation of systemic and localized plant defense mechanisms. The protection mechanism used by $P$. ostreatus may be attributed to the production of secondary metabolites such as phenolic compounds. These phenolic compounds participate in the regulation of stages the development, and also contribute to the defense responses during exposure to pathogen infection, extreme sunlight, heavy metal stress and injuries. Such compounds often possess antioxidant activity, which is attributed to their unique chemical structure. Plant defense mechanisms based on phenolic compounds include physical changes, such as increasing lignification and suberization of the plant cell walls, as well as metabolic changes such as the de novo synthesis of pathogenesis-related (PR) proteins and biosynthesis and accumulation of phenyl propanoid secondary metabolites. This is in agreement with the results of Elsakhawy et al. (2020). The current results are in agreement with Bagyaraj (2018) who stated that AMF cannot offer complete immunity against the soil-borne pathogens, they only impart a degree of resistance against these pathogens. Meanwhile, PGPR facilitates AMF formation, and the synergistic interactions between AMF and PGPR may enhance bioprotection against soil-borne plant diseases.

The contents of total phenols in both treated varieties (Bright and Dark) were higher than their control plants. The content in total phenols, which are involved in defense mechanisms against pathogens was higher in treated plants with $F$. oxysporum than the control ones in both varieties (Sie et al., 2011). These compounds could be produced in response to the attacks of pathogens.

Photosynthetic pigments increased in response to microbiota inoculation may result from enhancing plant growth and biomass production. Bioagents may stimulate chlorophyll synthesis through encouraging pyridoxal enzymes formation, that play a role in $\alpha$-amino levulinic synthetase as a primary compound in chlorophyll synthesis. These results are supported by other published papers (Khalil et al., 2017 and Al-Sayed et al., 2020).

Vegetative growth parameters i.e., shoot length and number of branches recorded at harvest stage. Bio-fertilizer significantly increased growth parameters, which may be as a consequence of synthesis of phytohormones, $\mathrm{N}_{2}$ fixation, synthesis of some enzymes that modulate the level of plant hormones, solubilization of inorganic phosphate and mineralization of organic phosphate which makes phosphorus available for the plant, the synthesis of growth promoting compounds like cytokinins, gibberellins and IAA. These results are similar to those obtained by Khalil et al. (2017) and Al-Sayed et al. (2020). Increase number of calyxes may be imputable to the increment in the number of branches.

Shoot fresh and dry yield, calyx fresh and dry yield and seed yield were significantly increased under inoculation by the combined bioagents comparing to individual ones and the control. This may be ascribed to the collective effect of bioagents i.e., production of amino acids, vitamins and growth promoting substances like indole acetic and gibberellic acids secreted by 
these introduced beneficial microorganisms which resulted in enhanced nutrient uptake, translocation and synthesis of photosynthate assimilates which resulted increased plant growth characters. These results are compatible with those of El Naim et al. (2017), Khalil et al. (2017) and Al-Sayed et al. (2020).

It was clear that AM yield production was not effective when used individually. This is in agreement with Sembok et al. (2015) who found that AM spores were not effective in enhancing the above-soil vegetative growth or the yield of roselle calyxes.

Results presented here demonstrate that the inocula ( $P$. fluorescens and B. subtilis) were able to utilize a variety of compounds secreted by roselle, as a test plant, as carbon and energy sources where bacterial growth patterns were improved. As reported by Kipe-Nolt et al. (1985), bacteria utilize the exudates from a given genotype differentially. Many investigators (Kucey, 1988; Zaady and Okon, 1990) studied the root exudation phenomenon and concluded that, plants grown in soil under natural conditions are subjected to physical stresses which presumably bring about root-hair damage and the release of the organic zone.

The examination of the effect of root exudates on the growth of different PGPR strains revealed the higher ability of $P$. fluorescens to colonize roots than $B$. subtilis. In addition, different plant varieties affect the colonization of the same microbial strains. Root exudates are a mix of a wide variety of compounds, including primary and secondary metabolites. Primary metabolites, including carbohydrates, amino acids, and organic acids, are secreted in larger quantities than secondary metabolites, such as flavonoids, glucosinolates and auxins, etc. Root exudates mediate the interaction among plants of the same or different species, in a different manner depending on root exudate composition and the mechanisms of the relationship (Vives-Peris et al., 2019). This behavior is in agreement with Bais et al. (2004), who stated that chemical components of root exudates may deter one organism while attracting another, or two very different organisms may be attracted with differing consequences to the plant.

\section{CONFLICTS OF INTEREST}

The authors declare no conflict of interest exists.

\section{REFERENCES}

Al-Ali, A.; Deravel, J.; Krier, F.; Bechet, M.; Ongena, M. and Jacques, P. 2018. Biofilm formation is determinant in tomato rhizosphere colonization by Bacillus velezensis FZB42. Environ. Sci. Pollut. Res. Int., 25: 29910-29920.

Alanjary, M. and Medema, M.H. 2018. Mining bacterial genomes to reveal secret synergy. J. Biol. Chem., 293: 19996-19997.

Alexander, D.B. and Zuberer, D.A. 1991. Use of chrome azurol $S$ reagents to evaluate siderophore production by rhizosphere bacteria. Bio. Fertil. Soils, 12: 39-45.

Al-Sayed, H.M.; Hegab, S.A.; Youssef, M.A.; Khalafalla, M.Y.; Almaroai, Y.A.; Ding, Z. and Eissa, M.A. 2020. Evaluation of quality and growth of roselle (Hibiscus sabdariffa $\mathrm{L}$.) as affected by bio-fertilizers. Journal of Plant Nutrition. 43(7): 1025-1035.

Bagyaraj, D.J. 2018. Arbuscular Mycorrhizal fungi and biological control of soil-borne plant pathogens. KAVAKA, 51: 1-6

Bais, H.P.; Park, S.; Weir T.L.; Callaway R.M. and Vivanco J.M. 2004. How plants communicate using the underground information superhighway. Trends in Plant Science, 9: 26-32.

Bilal, R.; Rasul, G.; Arshad, M. and Malik, K.A. 1993. Attachment colonization and proliferation of Azospirillum brasilense and Enterobacter spp. on root surface of grasses, World J. Microbial. and Biotech., 9: 63-69.

El Naim, A.M.; Ahmed, A.I.; Ibrahim, K.A.; Suliman, A.M. and Babikir, E.S.N. 2017. Effects of nitrogen and bio-fertilizers on growth and yield of roselle (Hibiscus sabdariffa var sabdariffa L.). International Journal of Agriculture and Forestry, 7(6): 145-150.

El-Gamal, N.G.; Shehata, A.N.; Hamed E.R. and Shehata, H.S. 2016. Improvement of lytic enzymes producing Pseudomonas fluorescens and Bacillus subtilis isolates for enhancing their biocontrol potential against root rot disease in tomato plants. Research Journal of Pharmaceutical, Biological and Chemical Sciences, 7(1): 1393-1400.

Elsakhawy, T.; Alkahtani, M.D.F.; Sharshar A.A.H.; Attia K.A.; Hafez, Y.M. and Abdelaal, Kh.A.A. 2020. Efficacy of mushroom metabolites (Pleurotus ostreatus) as a natural product for the suppression of Broomrape growth (Orobanche crenata 
Forsk) in faba bean plants. Plants, 9(10): 1265.

FAO. 2018. FAOSTAT. Food and Agriculture Organization of the UN. Acc. Jun 2020 http:// www.fao.org/giews/english/cpfs/index.htm\# 2015.

Fokemma, N.J. 1973. The role of saprophytic fungi in antagonism against Derchslera sorokaniana (Helminthosporium sativum) on agar plates and on rye leaves with pollen. Physiol. Mol. Plant Pathol., 3: 195-205.

Franco-Sierra, N.D.; Posada, L.F.; Santa-Maria, G.; Romero-Tabarez, M.; Villegas-Escobar, V. and Alvarez, J.C. 2020. Bacillus subtilis EA-CB0575 genome reveals clues for plant growth promotion and potential for sustainable agriculture. Functional \& Integrative Genomics, 20: 575-589.

Gao, S.; Wu, H.; Yu, X.; Qian, L. and Gao, X. 2016. Swarming motility plays the major role in migration during tomato root colonization by Bacillus subtilis SWR01. Biological Control. https://doi.org/10.1016/j.biocontrol.2016.03. 011.

Gouda, S.; Kerry, R.G.; Das, G.; Paramithiotis, S.; Shin, H. and Patra J.K. 2018. Revitalization of plant growth promoting rhizobacteria for sustainable development in agriculture. Microbiological Research, 206: 131-140.

Gu, X.; Zeng, Q.; Wang, Y.; Li, J.; Zhao, Y.; Li, Y. and Wang, Q. 2021. Comprehensive genomic analysis of Bacillus subtilis 9407 reveals its biocontrol potential against bacterial fruit blotch. Phytopathology Research. 3, 4 (2021) https://doi.org/10.1186/s42483-021-00081-2.

Hashem, H.A.E.A.; El-Hadidy, A.E.A. and Ali, E.A. 2017. Impact of some safe agricultural treatments on insect pests, vascular wilt disease management and Roselle (Hibiscus sabdariffa L.) productivity under Siwa Oasis conditions. International Journal of Environment, 6(4): 139-162.

Hashem, A.; Tabassum, B. and Abd-Allah, E.F. 2019. Bacillus subtilis: A plant-growth promoting rhizobacterium that also impacts biotic stress. Saudi J. Biol. Sci., 26(6):12911297.

Hassan, N.; Elsharkawy, M.M.; Shimizu, M. and Hyakumachi, M. 2014. Control of root rot and wilt diseases of Roselle under field conditions. Mycobiology, 42(4): 376-384.

Khalil, A.A.; Hassan, F.A.S. and Ali, E.F. 2017. Influence of bio-fertilizers on growth, yield and anthocyanin content of Hibiscus sabdariffa L. plant under Taif Region conditions. Annual Research \& Review in Biology, 17(1): 1-15.

Kiely, P.D.; Haynes, J.M.; Higgins, C.H.; Franks, A.; Mark, G.L.; Morrissey, J.P. and O'Gara, F. 2006. Exploiting new systems-based strategies to elucidate plant-bacterial interactions in the rhizosphere. Microbial. Ecol., 51: 257-266.

Kipe-Note, J.A; Avalakki, U.K. and Dart P.J. 1985. Root exudation of sorghum and utilization of exudates by nitrogen fixing bacteria. Soil Biology and Biochemistry, 17(6): 859-863.

Kucey, R.M.V. 1988. Alteration of size of wheat root systems and nitrogen fixation by associative nitrogen-fixing bacteria measured under field conditions. Can. J. Microbiol., 34: 735-739.

Lamichhane, J.R.; Dürr, C.; Schwanck, A.A.; Robin, M.H.; Sarthou, J.P.; Cellier, V.; Messéan, A. and Aubertot, J.N. 2017. Integrated management of damping-off diseases: A review. Agron. Sustain. Dev. 37: 10

Leslie, J.F. and Summerell, B.A. 2006. The Fusarium Laboratory Manual. Blackwell Publishing Professional. 2121 State Avenue, Ames, Iowa 50014. USA. p399.

Lorck, H. 2004. Production of hydrocyanic acid by bacteria. Plant Physiol. 1: 142-146.

Metzner, H.; Rau, H. and Senger, H. 1965. Untersuchungen Zur Synchronisier barkeep ein Zelner pigment. Mango I Mutanten Von chlorella. Planta, 65: 186-194.

Miller, G.L. 1959. Use of Dinitrosalicylic acid reagent for determination of reducing sugar. Analytical Chemistry, 31(3): 426-428.

Mohamed, B.B.; Sulaiman, A.A. and Dahab, A.A. 2012. Roselle (Hibiscus sabdariffa L.) in Sudan, Cultivation and Their Uses. Bull. Environ. Pharmacol. Life Sci., 1(6): 48-54

Mohamed, N.T.; Mohsen, M.M.A.; Ismail H.; Abd El-All, A.A.M. and Shehata, H.SH. 2015. Biological control of Pelargonium graveolens diseases and impacts on oil contents and essential crop parameters. Egypt. J. of Appl. Sci., 30(5): 118-144.

Monreal, J and Reese, E.T. 1969. The chitinase of Serratia marcescens. Can. J. Microbiol., 15: 689-696.

Nielsen, M.N.J.; Sorensen, J.; Fels, J. and Pederrsen, H.C. 1998. Secondary metabolites and chitinase dependent antagonism toward plant pathogenic micro fungi of Pseudomonas 
fluorescens isolated from sugar beet rhizosphere. Applied Environ. Microbiol., 64: 3563-3569.

Ooi K.H. and Saleh B. 1999. Vegetative compatibility groups of Fusarium oxysporum, the causal organism of vascular wilt on roselle in Malasyia. Biotropia., 12: 31-41.

Ottai, M.; Abdel-Moniem, A. and El-Mergawi, R.A. 2011. Effect of variety and location on growth and yield components of Roselle, Hibiscus sabdariffa $\mathrm{L}$. and its infestation with the spiny bollworm Earias insulana (BOISD.) Archives of Phytopathology and Plant Protection. 37(3): 215-231.

Purseglove, J.W. 1974. Tropical Crops: Dicotyledons. Longman, London. pp 719.

Sahu, B.; Singh, J.; Shankar G. and Pradhan A. 2018. Pseudomonas fluorescens PGPR bacteria as well as biological agent: A review. International Journal of Chemical Studies, 6(2): 1-7.

Sarhan, E.A.D. and Shehata, H.S. 2014. Potential plant growth promoting activity of Pseudomonas spp. and Bacillus spp. as biocontrol agents against damping-off in alfalfa. Plant Pathology Journal, 13(1): 8-17.

Sembok, W.Z.W.; Abu Kassim, N.H.; Hamzah, Y. and Abd Rahman, Z. 2015. Effects of mycorrhizal inoculation on growth and quality of roselle (Hibiscus sabdariffa L.) grown in soilless culture system. Malays. Appl. Biol., 44(1): 57-62.

Shehata, H.S. 1997. Complementation of diazotroph inoculation and nitrogen fertilization to improve crop production under rigorous environmental conditions. M.Sc. Thesis. Faculty of Agriculture, Cairo University.

Sie, R.S.; Charles, G.; Diallo, H.A.; Kone, D.; Toueix, Y.; Dje, Y. and Branchard, M. 2011. Breeding of Hibiscus sabdariffa L.: evaluation of resistance to Fusarium oxysporum Schlecht. Emend. Snyd. and Hans in two varieties. Agriculture and Biology Journal of North America, 2(1): 125-133.

Sinclair, J. and Dhingra, O. 1995. Basic Plant Pathology Methods. $2^{\text {nd }}$ Edition Boca Raton: CRC Press, 448 pp.

Sindhu, S.S. and Sharma, R. 2020. Plant growth promoting rhizobacteria (PGPR): A sustainable approach for managing soil fertility and crop productivity. In: Malik D. K., Rathi M., Kumar R. and Bhatia D. Microbes for Humankind and Application. Daya Publishing House. A Division of Astral International Pvt. Ltd. pp 652
Sindhu, S.S.; Sehrawat, A.; Sharma, R. and Dahiya, A. 2016. Biopesticides: use of rhizosphere bacteria for biological control of plant pathogens. Def. Life Sci. J., 1(2):135148.

Skujins, J. 1976. Extracellular enzymes in soil. CRC Critical Reviews in Microbiology, 4: 383-421.

Snedecor, G.A. and Cochran, W.G. 1980. Statistical Methods, $7^{\text {th }}$ Ed., The Iowa State Univ., Press, Ames., Iowa, U.S.A.507p.

Somogyi, M.J. 1945. Notes on sugar determination. Biol. Chem., 195: 19-23.

Tsegaye, Z.; Assefa, F. and Beyene, D. 2017. Properties and application of plant growth promoting rhizobacteria. Int. J. Trend. Pharmcobiol. Med. Sci., 2(1): 30-43.

Vancura, V. and Hanzlikova, A. 1972. Root exudates of plants. IV. Differences in chemical composition of seed and seedling exudates. Plant and Soil, 36: 271-282.

Vejan, P.; Abdullah, R.; Khadiran, T.; Ismail, S. and Boyce, A.N. 2016. Molecules. role of plant growth promoting rhizobacteria in agricultural sustainability-A Review. Molecules, 21(5):573.

Vives-Peris, V.; De Ollas, C.; Gómez-Cadenas, A. and Pérez-Clemente, R.M. 2019. Root exudates: from plant to rhizosphere and beyond. Plant Cell Reports, 39: 3-17.

Voisard, C.; Keel C.; Haas, D. and Defago, G. 1989. Cyanide production by Pseudomonas fluorescens helps suppress black root rot of tobacco under gnotobiotic conditions. EMBO Journal, 8: 351-358.

Weller, D.M. 1988. Biological control of soil borne plant pathogens in the rhizosphere with bacteria. Ann. Rev. Phytopathol., 26: 379407.

Zaady, E. and Okon, Y. 1990. Cultural conditions affecting Azospirillum brasilense cell aggregation and adsorption to maize roots. Soil Biol. Biochem., 22(8): 1103-1107.

Zian, A.H. and Aly, M.M. 2020. Impact of coinoculation with Rhizobium leguminosarum and some plant growth promoting Rhizobacteria against Rhizoctonia solani and Fusarium oxysporum infected faba bean. Journal of Plant Protection and Pathology. 11(9):441-453.

Zieslin, N. and Ben-Zaken, R. 1993. Peroxidase activity and presence of phenolic substances in peduncles of rose flowers. Plant Physiol. Biochem., 31: 333- 339. 